\title{
Disparate faculty perspectives on system changes in higher education
}

\author{
Joaquim S. Silva $^{\mathrm{a}}$, Paulo Peixoto ${ }^{\mathrm{b}}$ and Adelaide Freitas ${ }^{\mathrm{c}}$
}

${ }^{a}$ Coimbra School of Agriculture, Polytechnic Institute of Coimbra, 3045-601 Coimbra, Portugal; ${ }^{b}$ Centre for Social Studies, University of Coimbra, Apartado 3087, 3000-995 Coimbra, Portugal; ' Department of Mathematics \& CIDMA, University of Aveiro, 3810-193 Aveiro, Portugal

Contact: Joaquim S. Silva $\quad \underline{\text { jss@esac.pt }}$

This is an Accepted Manuscript of an article published by Taylor \& Francis in Higher Education Research \& Development on 2018, available at https $/ /$ www.tand fonline.com/doi/full/10.1080/07294360.2017.1411338 


\section{Disparate faculty perspectives on system changes in higher education}

Higher education (HE) systems around the world have experienced profound structural changes particularly since the late 1960s - early 1970s, essentially driven by the need to expand access to tertiary education. This has resulted in a diversity of HE institutions (HEI) with different roles, missions and statuses, as well as academic staff with diverse perspectives and motivations. The present study is based on a survey undertaken in Portugal by a trade union, aimed to collect faculty perspectives on a proposed HE reform sent out for public discussion by the Government. Questions addressed the reorganization of the HEI network, the internal restructuring of HEI, the funding system and the binary divide of HEI (universities and polytechnics). The survey results showed a disparity of faculty perspectives about the proposed reform, closely related to the diversity of HEI. Respondents from lower academic categories and from smaller HEI were more opposed to reorganizing the HEI network. This reorganization was more widely accepted by university staff, who were also more in favour of a binary system than were polytechnic respondents. Although there was general agreement about the need to change the funding system, polytechnic respondents were strongly against a funding differentiation between universities and polytechnics. Despite an overall reformist trend, the enthusiasm for reforms declined substantially when the questions had a direct reference to the respondent's region or institution. It is argued that HE expansion has driven the diversification of HEI, leading to a range of perspectives about the HE system and the way it should be changed. These conclusions may contribute to insights into other HE systems around the world where institutional diversification has been sought by public policies.

Keywords: academic staff; higher education policy; structural change; binary system; Portugal 


\section{Introduction}

One of the most important trends in higher education (HE) has been the continued and almost generalized expansion of national HE systems since the 1960s (e.g. GuriRosenblit, Šebková, \& Teichler, 2007). This widespread trend has been accompanied by a diversification of HE institutions (HEI) which, following a market logic, have been designed or have simply evolved to suit an increasingly diverse demand. This major trend in HE systems has resulted in the conversion of the classical and elitist Humboldtian university with a strong universal identity, into the so-called 'multiversity', a term coined by Clark Kerr about half century ago (Kerr, 1963), with a diversity of roles, missions and statuses. In some HE systems the multiversity has mostly an inter-institutional character whereas in others it has a strong intra-institutional dimension. In either case it may lead to strong diversity among academic staff (Henkel, 2016), who may develop different, frequently opposing, interests and therefore perspectives about the HE system. The development of opposing interests may be strongly prompted when system changes are proposed. Indeed, as in other areas of activity, structural reforms in $\mathrm{HE}$ seem to foster competition and polarization between the potential winners and losers (Ylijoki, 2014) that result from the proposed changes. It is very important to assess these different perspectives and the reasons behind them, as it may help, for example, to understand the resistance of some faculty groups to the introduction of system changes or to explain the development of frictions among the academic community because of opposing interests.

Based on this rationale, the present paper draws on a literature review and on empirical findings to assess the diversity of faculty perspectives on system changes in $\mathrm{HE}$ and to test the hypothesis that this diversity can be related to the diversification of HEI caused by HE expansion. Empirical data were obtained from an online survey querying the 
faculty members of Portuguese HEI, about a proposed reform sent out for discussion by the Government.

\section{Major trends in higher education systems}

The generalized trend of HE expansion initiated in the 1960s was, in many countries, accompanied by the creation of vocational HE institutions (HEI) adding to the existing universities and resulting in a 'binary system'. The UK and Australia were among the first countries (during the 1950s and the 1960s) to implement this model (Mahony, 1994), which was later adopted by others. While some binary systems managed to thrive by keeping clear dividing lines, others degenerated towards blurred boundaries (Huisman \& Kaiser, 2001; Schubert et al., 2014; Shanahan \& Jones, 2007) because of the so-called 'academic drift' leading to a convergence between vocational HEI and research-based HEI (e.g. Bowden \& Anwyl, 1983; Huisman \& Kaiser, 2001; Shanahan \& Jones, 2007; Witte, Van der Wende, \& Huisman, 2008). In Europe, this blurring trend became more evident after the Bologna Reform in the early 2000s, through an homogenization of HEI which weakened the existing binary systems (Teichler, 2008; Witte et al., 2008). Meanwhile, both the UK and Australia had reversed their previous reforms by abolishing their binary systems in the early 1990s, (Mahony, 1990, 1994). However, while Australia has created a Unified National System of comprehensive universities through merging processes, in the UK there was simply a conversion of polytechnics into universities, resulting in a marked vertical stratification of HEI (Mahony, 1994). Economic sustainability was in part at the origin of these new reforms, somehow strengthening the tendency towards economic-driven changes in HE. The decrease in student enrolment in some countries has contributed to boosting this tendency (e.g. Hay \& Fourie, 2002). 
In this new context of economic efficiency and sustainability, two important trends have been present in many HE systems since the 1990s: a performance-based governance of HEI within the so-called New Public Management (e.g. Carvalho \& Bruckmann, 2014) and the process of mergers and consortia among HEI (Flora \& Hirt, 2010; Pruvot, Eastermann, \& Mason, 2015). Although prompted by specific Government initiatives (e.g. Boer \& Goedegebuure, 2007), the still-ongoing move into a managerial culture has been subtle (some would call it insidious) resulting in an 'evolutionary change' according to Gamage (1992, p. 176). On the contrary, institutional mergers are good examples of 'planned changes' in HE (Gamage, 1992, p. 176). The creation in Australia of a Unified National System of universities in only five years, is probably one of the most radical planned changes in the history of HE (Mahony, 1995).

\section{Faculty perspectives about system changes in higher education}

The large body of literature about mergers in HE, contrasts with the fewer assessments of faculty perspectives about these important structural changes. Some reports suggest an overall agreement of the academic staff about merging initiatives if they are implemented on a voluntary basis (Hay \& Fourie, 2002; Pruvot et al., 2015; Skodvin, 1999). However, others emphasize resistance of faculty members, driven by insecurity and identity loss (Evans, 2015; Puusa \& Kekäle, 2015). Merging processes may result in profound dissatisfaction as reported by Verhoeven (2008), because of the drastic changes that are imposed at the organizational and staff levels. Even more relevant is the case of mergers among formally distinct institutions, as in the case of the Australian reform towards a unified HE system. According to Mahony (1995), staff from merged institutions felt that the aimed institutional integration had not been achieved and that 
conflicts within the new institutions had eventually been the dominant short-term outcome of these mergers.

As in the case of mergers in HE, there are not many assessments of faculty perspectives on academic drift. Two references from the Netherlands suggest that staff from Dutch vocational HEI supported this change, based on the assumption that research can improve esteem, the quality of education and the link with business companies (de Weert, 2015; Griffioen \& de Jong, 2013). However, another assessment based on a survey from Belgium, concluded that college teachers were "not filled with enthusiasm for academic drift' (Verhoeven, 2008, p. 70). Moreover, an international survey revealed that in five out of seven studied countries, less than $50 \%$ of the staff from vocational HEI had preference for research activities (de Weert, 2015). Similar results were presented by Bowden \& Anwyl (1983) before the collapse of the binary system in Australia.

\section{Changes in the Portuguese higher education system}

As in other countries, the Portuguese public HE system has undergone various changes since the 1970 s, essentially led by the general aim of expanding access to tertiary education (Almeida \& Vieira, 2012; Magalhães, Amaral, \& Tavares, 2009). A binary system separating HE into university and polytechnic subsystems was created and consolidated at the end of the 1970s and beginning of the 1980s. This process led to a complex network (Kauko \& Diogo, 2012) of public institutions which currently comprises 14 universities and 15 polytechnics. Additionally, there are 12 independent schools (five in the university subsystem and seven in the polytechnic subsystem) that are not institutionally integrated in any polytechnic or university. Half of the public universities also host polytechnic schools (18 schools in total). After a period of 
expansion and diversification, the Portuguese HEI network started a phase of increasing vertical stratification among similar institutions driven by a decrease in student enrolment due to demographic reasons (Fonseca, Encarnação, \& Justino, 2014). This process affected particularly the polytechnic subsystem and in general the HEI located outside the main urban centres (Amaral \& Magalhães, 2005). The financial crisis that touched Portugal, particularly after 2010, prompted a renewed need for reforms aimed at increasing system efficiency, while maintaining the binary system. Thus, in 2013 the Government launched an open discussion about a proposed reform of public HEI. The guidelines of this reform included: the reorganization of the HEI network through consortiums and/or mergers, regulated by regional bodies; the coordination of educational offer among institutions; the internal rationalization of HEI; and the improvement of the funding system. In 2015, the Government proposed a redistribution of public funds according to new criteria, and sent out a new funding model for discussion. However, no concrete policy measures have ever been put in force after these public discussions, despite several announcements in this regard.

\section{Assessing faculty perspectives on proposed changes in the Portuguese HE system}

\section{Methodology}

The results of an online survey launched by the National Union for Higher Education (SNESup) were analysed to assessing the opinion of faculty members about a reform sent out for public discussion by the Portuguese Government in October 2013. SNESup is a trade union that represents teaching and research staff from public and private Portuguese HEI. Since the reform was focused on the public sector, the survey was only addressed to teaching and research staff of public institutions. Replies were collected 
during the public discussion along two weeks using the Survey Monkey tool (www.surveymonkey.com). The online survey was widely disseminated by email to all public HEI. Participation was voluntary and respondent anonymity was guaranteed.

For the purposes of the present study respondents were characterized according to five factors, each one comprising two or three strata (Table 1): Subsystem (university, polytechnic), HEI location (littoral, interior), Professional Category (1, 2, 3), Gender (male, female) and SNESup member (Yes/No). HEI location resulted from a reclassification of the exact locations of HEI. Littoral HEI includes institutions located in highly populated coastal areas, whereas interior HEI includes smaller institutions from inner regions and two universities from the archipelagos of Madeira and Azores. Professional Category is also the result of a simplification aimed to reduce the number of strata and to harmonize the categories of polytechnic and university staff. Category 1 corresponds to lower academic positions (e.g. lecturer), Category 3 to higher academic positions (e.g. full professor) and Category 2 to intermediate levels. 
Table 1 Absolute frequencies and percentages of each stratum compared to: the respondents who replied to the nine questions $(n=998)$, the group of respondents who replied to at least one question $(n=2719)$, and the population under study $(n=25528)$. Only respondents who included information on the five characterization factors were considered.

\begin{tabular}{|c|c|c|c|c|c|c|}
\hline \multirow{2}{*}{ Factor } & \multirow{2}{*}{ Strata } & \multicolumn{2}{|c|}{9 questions } & \multicolumn{2}{|c|}{$\geq 1$ question } & \multirow{2}{*}{$\frac{\text { population }}{\%}$} \\
\hline & & $\mathrm{n}$ & $\%$ & $\mathrm{n}$ & $\%$ & \\
\hline \multirow[t]{2}{*}{ Subsystem } & University & 474 & 47.5 & 1486 & 54.7 & 61.0 \\
\hline & Polytechnic & 524 & 52.5 & 1233 & 45.3 & 39.0 \\
\hline \multirow[t]{2}{*}{ HEI location } & Littoral & 693 & 69.4 & 1943 & 71.5 & 81.0 \\
\hline & Interior & 305 & 30.6 & 776 & 28.5 & 19.0 \\
\hline \multirow[t]{3}{*}{ Category } & 1 & 162 & 16.2 & 444 & 16.3 & 22.0 \\
\hline & 2 & 600 & 60.1 & 1705 & 62.7 & 46.6 \\
\hline & 3 & 236 & 23.6 & 570 & 21.0 & 31.4 \\
\hline \multirow[t]{2}{*}{ Gender } & Male & 643 & 64.4 & 1560 & 57.4 & 56.6 \\
\hline & Female & 355 & 35.6 & 1159 & 42.6 & 43.4 \\
\hline \multirow[t]{2}{*}{ SNESup member } & Yes & 338 & 33.9 & 880 & 32.4 & 12.2 \\
\hline & No & 660 & 66.1 & 1839 & 66.6 & 87.8 \\
\hline
\end{tabular}


A set of 21 multiple-choice and open-ended questions queried the respondents about the HE system and the proposed reform but only nine questions were retained for the present study (Table 2); open-ended-questions and specific questions about the regional arrangement of $\mathrm{HEI}$, not relevant for an international readership, were discarded. Reply to each question was non-compulsory, therefore resulting in different return rates. The nine questions correspond to three distinct topics: the reorganization of the HEI network (Questions 1-3; hereafter Q1-Q3); the internal restructuring of HEI in terms of educational offer and staff qualifications (Q4-Q6); and the current HE system (binary divide and funding; Q7-Q9). According to an official free-access online database (http://www.dgeec.mec.pt/np4/rebides/) Portuguese public HEI had 25528 faculty members in 2012, corresponding to the pool of potential respondents. The online survey registered 3609 entries, from which: 2719 respondents replied to at least one of the nine questions (10.7\% of potential respondents) and 998 respondents replied to all nine questions (3.9\% of potential respondents). 
Table 2 Summary statistics of survey replies to each question.

\begin{tabular}{|c|c|c|c|}
\hline Question & Reply & $\mathrm{n}$ & $\%$ \\
\hline \multirow{2}{*}{$\begin{array}{l}1-\text { Do you agree with the reorganization of the HEI network at the national } \\
\text { level? }\end{array}$} & Yes & 1886 & 69.3 \\
\hline & No & 835 & 30.7 \\
\hline \multirow{2}{*}{$\begin{array}{l}2-\text { Do you agree with the reorganization of the HEI network in your region, } \\
\text { following the regional framework adopted in the Dispatch which regulates } \\
\text { the educational offer in 2013-14? }\end{array}$} & Yes & 1248 & 47.6 \\
\hline & No & 1372 & 52.4 \\
\hline \multirow{2}{*}{$\begin{array}{l}3 \text { - Do you agree with the creation of regional structures to coordinate the } \\
\text { HEI network and the educational offer? }\end{array}$} & Yes & 1269 & 50.2 \\
\hline & No & 1258 & 49.8 \\
\hline \multirow{2}{*}{$\begin{array}{l}4-\text { Do you agree with the necessity of restructuring the functioning of HEI } \\
\text { in general? }\end{array}$} & Yes & 1774 & 89.6 \\
\hline & No & 207 & 10.4 \\
\hline \multirow{2}{*}{$\begin{array}{l}5-\text { Do you agree with the necessity of restructuring the functioning of HEI } \\
\text { in the specific case of your sub-system? }\end{array}$} & Yes & 1471 & 78.5 \\
\hline & No & 402 & 21.5 \\
\hline \multirow{2}{*}{$\begin{array}{l}6-\text { Do you agree with the necessity of restructuring the functioning of HEI } \\
\text { in the specific case of your institution? }\end{array}$} & Yes & 1382 & 73.3 \\
\hline & No & 504 & 26.7 \\
\hline \multirow{2}{*}{$\begin{array}{l}7-\text { Do you agree with the existing binary division in higher education } \\
\text { (university and polytechnic)? }\end{array}$} & Yes & 1539 & 68.3 \\
\hline & No & 714 & 31.7 \\
\hline \multirow{2}{*}{$\begin{array}{l}8-\text { Do you think it is necessary to change the existing funding system of } \\
\text { HEI? }\end{array}$} & Yes & 1543 & 89.9 \\
\hline & No & 174 & 10.1 \\
\hline \multirow{2}{*}{$\begin{array}{l}\text { 9- Should the funding be differentiated between university and polytechnic } \\
\text { subsystems? }\end{array}$} & Yes & 596 & 35.8 \\
\hline & No & 1068 & 64.2 \\
\hline
\end{tabular}


One major drawback of online surveys is the difficulty of obtaining a sample that is representative of the population under study, due to non-response bias (Couper, Kapteyn, Schonlau, \& Winter, 2007). Non-response bias was assessed by applying weighted bootstrap resampling techniques based on the percentile method (Efron \& Tibshirani, 1994) to compute $95 \%$ confidence intervals (CI) of the estimated proportions of agreement for each question. Confidence intervals were obtained by extracting 1000 samples, weighted according to the strata proportions in the population, for each of the five characterization factors.

A cluster analysis was applied to the subset of 998 complete questionnaires, (i.e. respondents who answered all nine questions), aiming to find groups of respondents with a similar reply pattern. An agglomerative hierarchical clustering method used was used to produce a dendrogram for respondents and another for questions. Euclidean distance was used to measure dissimilarity. The complete linkage (respondents) and the average linkage (questions) were used as agglomerative criteria. A heatmap was built using the $998 \times 9$ binary (respondents $\mathrm{x}$ questions; Yes/No replies) data matrix, to help in the identification of clusters of respondents. Two-sided chi-square tests of one proportion with continuity correction were performed to assess the existence of differences in frequency distribution between each cluster and the subset of 998 respondents. This procedure was used both for the proportions of "Yes" replies among the nine questions as for the proportions of respondents' strata within each characterization factor.

Cramer's V coefficient of association was computed for each combination between the nine dichotomous questions and the five characterization factors, to check for dependency relationships between respondents' strata and the proportion of 'Yes" 
replies. A weighted bootstrap approach similar to the procedure described above, was used to evaluate the effect of non-response bias on these relationships. All analytical procedures were performed using $\mathrm{R}$ software (R Core Team, 2015).

\section{Survey results}

Overall results show that $69.3 \%$ of respondents were in favour of reorganizing the $\mathrm{HE}$ network in Portugal (Q1; Table 2). However, the proportion of positive replies was much lower when the questions specifically referred the region of the respondent (47.6\% and 50.2\% for Q2 and Q3, respectively). As to the internal restructuring of HEI (Q4), there was also a high percentage $(89.6 \%)$ in favour of such change but again, when asked about the possibility of reforming institutions within the respondent subsystem, the agreement was lower $(\mathrm{Q} 5 ; 78.5 \%)$ and even lower when asked about the implementation of such measures in the respondent's institution (Q6; 73.3\%). There were $68.3 \%$ of respondents who agreed with the existing binary system (Q7) but there was a much lower agreement about a differentiation of public funding between polytechnics and universities (Q9; 35.8\%). However, the reply to this latter question was biased by the higher percentage of polytechnic (bootstrap $\mathrm{CI}=38.6 \%, 43.4 \%$ ) and SNESup (bootstrap $\mathrm{CI}=36.7 \%, 41.5 \%$ ) respondents compared to the actual population. The clear majority of respondents were in favour of changes in the funding system of HEI (Q8; 89.9\%). 
Table 3 Percentage of "Yes" replies for each question and for each heatmap cluster (Fig. S1 in Supplemental online material). Significance levels correspond to two-sided chi-square tests between each cluster and the overall subset of complete questionnaires (column All): * $\mathrm{p}<0.05 ; * * \mathrm{p}<0.01 ; * * * \mathrm{p}<0.001 ; \mathrm{ns}-$ non- significant.

\begin{tabular}{|c|c|c|c|c|c|}
\hline Questions & $\begin{array}{l}\text { Cluster } 1 \\
(n=188)\end{array}$ & $\begin{array}{l}\text { Cluster } 2 \\
(n=739)\end{array}$ & $\begin{array}{l}\text { Cluster } 3 \\
\qquad(n=71)\end{array}$ & $\begin{array}{l}\text { Cluster } 4 \\
\qquad(n=85)\end{array}$ & $\begin{array}{c}\text { All } \\
(n=998)\end{array}$ \\
\hline Question 1 & $28.7 \% * * *$ & $78.8 \% * * *$ & $81.6 \% \quad *$ & $100 \% * * *$ & $69.5 \%$ \\
\hline Question 2 & $8.0 \% * * *$ & $59.0 \% * * *$ & $23.9 \% * * *$ & $100 \% * * *$ & $46.9 \%$ \\
\hline Question 3 & $7.4 \% * * *$ & $55.9 \% * * *$ & $33.8 \% \mathrm{~ns}$ & $100 \% * * *$ & $45.2 \%$ \\
\hline Question 4 & $47.3 \% * * *$ & $99.2 \% * * *$ & $70.4 \% * * *$ & $100 \% * * *$ & $87.4 \%$ \\
\hline Question 5 & $19.1 \% * * *$ & $99.1 \% * * *$ & $46.5 \% * * *$ & $100 \% * * *$ & $80.3 \%$ \\
\hline Question 6 & $19.7 \% * * *$ & $94.6 \% * * *$ & $52.1 \% * * *$ & $100 \% * * *$ & $77.5 \%$ \\
\hline Question 7 & $64.9 \% \mathrm{~ns}$ & $58.3 \% \quad *$ & $88.7 \% * * *$ & $100 \% * * *$ & $62.0 \%$ \\
\hline Question 8 & $65.0 \% * * *$ & $95.2 \% * * *$ & $95.8 \% \mathrm{~ns}$ & $100 \% * *$ & $89.6 \%$ \\
\hline Question 9 & $20.2 \% * * *$ & $37.2 \%$ ns & $78.9 \% * * *$ & $100 \% * * *$ & $37.0 \%$ \\
\hline
\end{tabular}


Three major clusters of respondents with similar replies to the nine questions were identified in the heatmap (Fig. S1 in Supplemental online material; Clusters1-3 in Table 3). Cluster 1 is defined by 188 respondents who predominantly replied "No" to most questions, except Q7 and Q8. The profile of respondents is similar to the complete data set ( $\mathrm{n}=998$, Table 4). Cluster 2 includes most respondents (739) and is predominantly composed of "Yes" replies to all questions, except Q9. The profile of respondents is also similar to the complete data set. Cluster 3 is defined by 71 respondents showing a predominant percentage of negative replies to Q2, Q3 and Q5. In this case, respondents from interior HEI and from Category 1 were less represented than in the complete data set, although only with marginal statistical significance ( $\mathrm{p}$-value $<0.10$ ). In Cluster 2 there is a group of 85 respondents who replied "Yes" to the nine questions (Cluster 4). This cluster had significantly less respondents from polytechnics, from Category 1 and from SNESup.

The results presented in Table $\mathbf{5}$ show that university respondents and higher categories tended to agree more with the reorganization of the HEI network at the national (Q1) and regional levels $(\mathrm{Q} 2)$ and with the creation of a regional coordination body (Q3). Littoral respondents had more positive replies to Q2 and male respondents had more positive replies to Q1 and Q2. Polytechnic respondents tended to agree more with the restructuring of HEI in general (Q5) and of their subsystem (Q6). Interior respondents had more positive replies to Q6. University respondents and non-members of SNESup tended to agree more with the binary system (Q7). Respondents from intermediate academic positions (Category 2) tended to disagree with changes in the funding system (Q8). University respondents, higher categories, male respondents and non-members of SNESup tended to agree more with a funding differentiation between the two subsystems (Q9). According to the weighted bootstrap resampling, all 
coefficients of association were within the $95 \% \mathrm{CI}$, except the combination Q9 vs.

SNESup member $(\mathrm{CI}=0.014,0.103)$.

Table 4 Observed percentages of respondents' strata in each cluster. Significance levels correspond to two-sided chi-square tests between each cluster and the overall subset of complete questionnaires (column All): * $\mathrm{p}<0.05 ; * * \mathrm{p}<0.01$; *** $\mathrm{p}<0.001$; ns - nonsignificant; $\mathrm{ns}^{*}$ - marginally significant $(\mathrm{p}<0.10)$.

\begin{tabular}{|c|c|c|c|c|c|c|c|c|c|c|}
\hline Factor & Strata & $\begin{array}{l}\text { Cluster } \\
(n=188)\end{array}$ & & $\begin{array}{l}\text { Cluster } \\
(n=739)\end{array}$ & & $\begin{array}{r}\text { Cluster } \\
(n=71)\end{array}$ & & $\begin{array}{r}\text { Cluster } \\
(n=85)\end{array}$ & & $\begin{array}{c}\text { All } \\
(n=998)\end{array}$ \\
\hline Subsystem & $\begin{array}{l}\text { University } \\
\text { Polytechnic }\end{array}$ & $\begin{array}{l}45.2 \% \\
54.8 \%\end{array}$ & ns & $\begin{array}{l}47.2 \% \\
52.8 \%\end{array}$ & ns & $\begin{array}{l}56.3 \% \\
43.7 \%\end{array}$ & ns & $\begin{array}{l}82.4 \% \\
17.6 \%\end{array}$ & $* * *$ & $\begin{array}{l}47.5 \% \\
52.5 \%\end{array}$ \\
\hline HEl location & $\begin{array}{l}\text { Littoral } \\
\text { Interior }\end{array}$ & $\begin{array}{l}68.1 \% \\
31.9 \%\end{array}$ & ns & $\begin{array}{l}70.8 \% \\
29.2 \%\end{array}$ & ns & $\begin{array}{l}59.2 \% \\
40.8 \%\end{array}$ & ns* & $\begin{array}{l}74.1 \% \\
25.9 \%\end{array}$ & ns & $\begin{array}{l}69.4 \% \\
30.6 \%\end{array}$ \\
\hline Category & $\begin{array}{l}1 \\
2\end{array}$ & $\begin{array}{l}17.6 \% \\
617 \%\end{array}$ & ns & $\begin{array}{l}16.8 \% \\
586 \%\end{array}$ & ns & $\begin{array}{r}7.0 \% \\
719 \%\end{array}$ & ns* & $\begin{array}{l}7.1 \% \\
682 \%\end{array}$ & $*$ & $16.2 \%$ \\
\hline & 3 & $20.7 \%$ & ns & $24.6 \%$ & ns & $21.1 \%$ & ns & $24.7 \%$ & ns & $23.7 \%$ \\
\hline Gender & $\begin{array}{l}\text { Male } \\
\text { Female }\end{array}$ & $\begin{array}{l}62.8 \% \\
37.2 \%\end{array}$ & ns & $\begin{array}{l}65.2 \% \\
34.8 \%\end{array}$ & ns & $\begin{array}{l}60.6 \% \\
39.4 \%\end{array}$ & ns & $\begin{array}{l}65.9 \% \\
34.1 \%\end{array}$ & ns & $\begin{array}{l}64.4 \% \\
35.6 \%\end{array}$ \\
\hline $\begin{array}{l}\text { SNESup } \\
\text { member }\end{array}$ & $\begin{array}{l}\text { Yes } \\
\text { No }\end{array}$ & $\begin{array}{l}33.0 \% \\
67.0 \%\end{array}$ & ns & $\begin{array}{l}33.8 \% \\
66.2 \%\end{array}$ & ns & $\begin{array}{l}36.7 \% \\
63.3 \%\end{array}$ & ns & $\begin{array}{l}20.0 \% \\
80.0 \%\end{array}$ & $*$ & $\begin{array}{l}33.9 \% \\
66.1 \%\end{array}$ \\
\hline
\end{tabular}


Table 5 Percentage of "Yes" replies for each question by respondents' strata. The second line indicates the number of replies (n) followed by the value of Cramer's V between factors and questions. Significant results are in bold. A grey background indicates a value of the V coefficient out of the range of the $95 \%$ CI weighted bootstrap. The significance level of each V value is coded as: $* \mathrm{p}<0.05 ; * * \mathrm{p}<0.01 ; * * * \mathrm{p}<0.001$.

\begin{tabular}{|c|c|c|c|c|c|c|c|c|c|c|}
\hline \multirow{2}{*}{$\begin{array}{l}\text { Factor } \\
\text { Strata }\end{array}$} & Subsystem & \multicolumn{2}{|c|}{ HEl location } & \multicolumn{3}{|c|}{ Category } & \multicolumn{2}{|c|}{ Gender } & \multicolumn{2}{|c|}{ SNESup member } \\
\hline & Univ & Littoral & Interior & 1 & 2 & 3 & Male & Female & Yes & No \\
\hline \multirow{2}{*}{ Question 1} & $71.9 \%$ & $69.0 \%$ & $70.0 \%$ & $58.9 \%$ & $69.3 \%$ & $77.8 \%$ & $70.9 \%$ & $67.2 \%$ & $69.2 \%$ & $69.4 \%$ \\
\hline & $\mathrm{n}=2721 ; 0.062^{* *}$ & \multicolumn{2}{|c|}{$n=2721 ; 0.010$} & \multicolumn{3}{|c|}{$\mathrm{n}=2632 ; 0.124^{* * *}$} & \multicolumn{2}{|c|}{$\mathrm{n}=2721: 0.040^{*}$} & \multicolumn{2}{|c|}{$n=2721 ; 0.001$} \\
\hline \multirow{2}{*}{ Question 2} & $52.7 \%$ & $49.5 \%$ & $43.2 \%$ & $41.0 \%$ & $47.7 \%$ & $52.8 \%$ & $49.4 \%$ & $45.2 \%$ & $46.5 \%$ & $48.2 \%$ \\
\hline & $\mathrm{n}=2620 ; 0.109 * * *$ & \multicolumn{2}{|c|}{$\mathrm{n}=2620 ; 0.057^{* *}$} & \multicolumn{3}{|c|}{$\mathrm{n}=2532 ; 0.071^{* *}$} & \multicolumn{2}{|c|}{$n=2620 ; 0.042^{*}$} & \multicolumn{2}{|c|}{$n=2620 ; 0.016$} \\
\hline \multirow{2}{*}{ Question 3} & $52.0 \%$ & $51.1 \%$ & $48.1 \%$ & $44.6 \%$ & $50.7 \%$ & $54.5 \%$ & $50.3 \%$ & $50.1 \%$ & $48.8 \%$ & $50.9 \%$ \\
\hline & $n=2527 ; 0.040^{*}$ & \multicolumn{2}{|c|}{$\mathrm{n}=2527 ; 0.028$} & \multicolumn{3}{|c|}{$n=2449 ; 0.061 *$} & \multicolumn{2}{|c|}{$n=2527 ; 0.002$} & \multicolumn{2}{|c|}{$n=2527 ; 0.019$} \\
\hline \multirow{2}{*}{ Question 4} & $89.6 \%$ & $89.1 \%$ & $90.6 \%$ & $90.3 \%$ & $89.3 \%$ & $90.4 \%$ & $89.5 \%$ & $89.6 \%$ & $88.2 \%$ & $90.2 \%$ \\
\hline & $n=1981 ; 0.002$ & \multicolumn{2}{|c|}{$n=1981 ; 0.022$} & \multicolumn{3}{|c|}{$n=1921 ; 0.017$} & \multicolumn{2}{|c|}{$n=1981 ; 0.001$} & \multicolumn{2}{|c|}{$n=1981 ; 0.030$} \\
\hline \multirow{2}{*}{ Question 5} & $75.8 \%$ & $77.8 \%$ & $80.2 \%$ & $81.5 \%$ & $77.8 \%$ & $79.6 \%$ & $80.0 \%$ & $76.6 \%$ & $79.9 \%$ & $77.9 \%$ \\
\hline & $\mathrm{n}=1873 ; 0.069 * *$ & \multicolumn{2}{|c|}{$n=1873 ; 0.027$} & \multicolumn{3}{|c|}{$n=1816 ; 0.034$} & $\mathrm{n}=1 \varepsilon$ & 0.040 & $\mathrm{n}=18$ & .023 \\
\hline Ouestion 6 & $71.1 \% \quad 75.8 \%$ & $71.7 \%$ & $77.0 \%$ & $74.1 \%$ & $73.1 \%$ & $74.1 \%$ & $74.4 \%$ & $71.6 \%$ & $75.1 \%$ & $72.4 \%$ \\
\hline & $n=1886 ; 0.053^{*}$ & $n=188$ & $.055^{*}$ & & $1828 ; 0$. & & $n=1 \varepsilon$ & 0.031 & $n=18$ & .029 \\
\hline Oustion 7 & $75.7 \%$ & $67.7 \%$ & $69.8 \%$ & $68.1 \%$ & $69.0 \%$ & $66.1 \%$ & $67.6 \%$ & $69.2 \%$ & $65.4 \%$ & $69.8 \%$ \\
\hline & $\mathrm{n}=2253 ; 0.169 * * *$ & $n=22$ & 0.021 & & $2181 ; 0$. & & $n=22$ & 0.017 & $n=22$ & 045* \\
\hline Ouction 8 & $89.5 \%$ & $90.3 \%$ & $88.8 \%$ & $93.1 \%$ & $88.5 \%$ & $91.4 \%$ & $89.1 \%$ & $90.9 \%$ & $91.2 \%$ & $89.2 \%$ \\
\hline & $n=1717 ; 0.014$ & $\mathrm{n}=17$ & 0.022 & & $1668 ; 0.0$ & & $\mathrm{n}=17$ & 0.029 & $n=1$ & .031 \\
\hline Ouection 9 & $61.0 \%$ & $36.1 \%$ & $35.1 \%$ & $25.7 \%$ & $37.0 \%$ & $41.6 \%$ & $39.3 \%$ & $30.9 \%$ & $27.8 \%$ & $39.9 \%$ \\
\hline & $\mathrm{n}=1664 ; 0.490 * * *$ & $\mathrm{n}=166$ & 0.010 & & 609; 0.10 & & $n=166$ & $086^{* * *}$ & $n=16$ & $120^{* * *}$ \\
\hline
\end{tabular}




\section{Interpretation of the survey results}

\section{Main opinion trends}

Overall, the survey revealed a disparity of faculty perspectives about the proposed reform. Groups identified in the cluster analysis reflect these different perspectives, which can be categorised according to two major opinion axes: a conservative/reformist attitude about the proposed reforms and a lower/higher agreement about the binary system. Respondents from Clusters 1 and 3 essentially represent the conservative trend, given their predominantly negative perspective about system changes, when compared to the subset of complete replies. These clusters are differentiated by a lower level of agreement regarding the binary system, in the former rather than in the latter. In Cluster 3 there is marginally significant evidence of a higher proportion of respondents from interior regions and from Category 2. Contrarily, Cluster 2 represents the reformist trend, as replies are predominantly in favour of changes, but with a lower (compared to the subset of complete replies) agreement regarding the binary system. Within this group, a subgroup of respondents (Cluster 4), mostly from universities, from higher categories and non-SNESup members, shows a high level of agreement regarding the binary system.

\section{Conservatives vs. reformists}

The comparison between the conservative and the reformist trends shows a clear dominance of the latter over the former, probably influenced by the decrease in student enrolment and the financial crisis that led to budget cuts in Portugal and in other countries (Ritzen, 2015). Concurrently, there was a feeling of deficient resource management within and between institutions, maybe motivated by the considerable 
overlapping of closely related courses offered by neighbour HEI (Blättler, Rapp, Solà, Davies, \& Teixeira, 2013), thus reinforcing the reformist trend. However, the enthusiasm for reforms declined substantially when the questions had a direct reference to the respondent's region or institution, and was not equally shared by the different strata of respondents. Although the financial crisis has affected all institutions, the decline in student enrolment was higher in those from interior regions and from the polytechnic subsystem (Blättler et al., 2013; Fonseca et al., 2014), meaning that these would be particularly targeted by a reorganization of the HEI network. Therefore, it is not surprising that respondents from universities and from littoral regions were more in favour of this reorganization, than those that would be more likely affected. In fact, the merging between HEI of different size and status is often seen as a take-over rather than a real merger (Evans, 2015; Pruvot et al., 2015; Ylijoki, 2014). This fear of change was also evident in the replies of respondents from Category 1 to the questions about the HEI network. Category 1 includes respondents with the least secure faculty positions, due to higher rates of non-permanent employment contracts (Santiago, Carvalho, \& Cardoso, 2015). The possibility that mergers could lead to a loss of jobs was probably the reason for a more conservative attitude of these respondents. Replies to questions about the internal reorganization of institutions revealed a less conservative attitude in polytechnic and interior respondents. The difficulties faced by polytechnic institutions to enrol new students (Amaral \& Magalhães, 2005), could be a major reason for a relatively higher agreement of these respondents regarding these questions. On the contrary, all strata of respondents showed a high agreement about changes in the funding system of HEI. At the time, Portugal was in the depths of an economic crisis and the budget of HEI suffered severe cuts due to austerity measures (Ritzen, 2015). Therefore, the strong agreement about changes in the funding system probably shows 
the expectation that these changes would lead to a better financial situation for HEI. Given the decreasing trend in student enrolment (a major funding criterion used by the Government), the possibility of adopting new funding criteria may have been an additional motivation of respondents to support changes in the funding system. These expectations were essentially wishful thinking, since the Government proposal on funding, sent for discussion (but not implemented) in 2015, did not consider an increase of the overall budget allocated to $\mathrm{HE}$, but simply a redistribution of funds, partly based on performance indicators, including student enrolment.

\section{Binary supporters vs. binary opponents}

Unlike the first opinion axis, there was not a clear predominance between binary supporters and binary opponents, considering the two questions involved. The number of supporters of the division between universities and polytechnics was higher than the number of opponents, but the existing funding differentiation between the two subsystems had much lower support. Replies about the binary system were strongly influenced by the subsystem of the respondent. The lower agreement of polytechnic respondents apparently reflects the effects of academic drift in the Portuguese HE system (Amaral \& Magalhães, 2005). As in other countries, this evolutionary change became stronger owing to the Bologna process (de Weert, 2015; Witte et al., 2008) and the increasing academic qualifications of the polytechnic staff (Mahony, 1995). Even less consensual was the funding differentiation between polytechnics and universities, with polytechnic respondents strongly against any difference. This disagreement may have resulted from the fact that polytechnics get less public funding than universities (Blättler et al., 2013; Ferreira, de Lourdes Machado, \& Santiago, 2008), so that 'difference' was perceived as less funding. Respondents from Category 1, which are 
more vulnerable to budgetary constraints, were also less in favour of such

differentiation. Being a union member also played an important role in the balance between binary supporters and opponents, with unionized respondents being less in favour of the existing system. The SNESup union is one of the few organizations which integrate staff from both subsystems according to a parity status. The perspective that all faculty members should share similar working conditions, may explain the lower support of SNESup members for the binary system.

\section{Representativeness of the survey}

The way a questionnaire is accessed by respondents and the motivation to participate may influence the results and therefore the conclusions of a survey (Moser \& Kalton, 2017). For example, the voluntary participation through a web-based service excludes those individuals who are less motivated/informed but who might have a specific opinion about the topic in question. In this study, the sample was biased in terms of SNESup membership (around $20 \%$ more members than in the overall population), probably because unionized respondents were better informed and more motivated to participate. However, the implications for the results were limited to the question about the funding differentiation between the two subsystems (Q9). Similarly, the predominance of polytechnic respondents may have biased the results obtained for this specific question, by increasing the number of positive replies. As to the remaining questions there was no statistical evidence that non-response bias could have affected the obtained results.

\section{Policy implications of the present study}

Results suggest a reasonable interest from faculty members about the proposed reform, 
considering the topic under discussion, the large pool of potential respondents and the online access to the survey. It should be mentioned that some public debates organized to discuss the reform, were highly attended. This participation points to a broad concern within academia about the possibility of system changes. Indeed, academics are not necessarily a group of professionals strictly focused on the management of their own careers, showing little interest or lack of opinion on wider organisational issues (O'Meara \& Bloomgarden, 2011). Henkel (2016) suggests that the multiversity of present times, fostered by a culture of New Public Management, tends to put the faculty members in the periphery of academic organizations. However, in times of possible changes, there can be a considerable involvement of academic staff in the discussion of those changes.

The motivation to participate in the survey was accompanied by a general perception that something needs to be changed in the HE system, given the predominance of the reformists over the conservatives. However, most respondents would support changes in the HE system but not in their region/institution, bringing the classical discussion around the social role of individual vs. collective interests (e.g. Coleman, 2009). This result also reflects the so-called NIMBY (Not-In-My-Backyard) syndrome, frequently mentioned in environmental planning (e.g. Burningham, 2000). As pointed out by Diefenbach (2007) this NIMBY attitude of academics may reveal a form of passive resistance to the so-called TINA (There-Is-No-Alternative) principle. Respondents may agree with an inevitable path to solve a problem, but will not actively contribute to the solution.

A marked diversity of attitudes and feelings was evident in the questions related to the HEI network and even stronger in the questions about the binary system, revealing a tough polarization among faculty members. This polarization can be linked 
to the existence of different professional identities and interests in binary systems (e.g. Bowden \& Anwyl, 1983; Carvalho, 2011), resulting in opposing forces striving to reach different goals and pulling in opposite directions. As Bowden \& Anwyl (1983, p. 40) pointed out decades ago about the results of an Australian survey, staff from the two subsystems 'most differ when they reflect on each other'. Both the binary system and the littoral vs. interior competition for students, have been a recurrent source of debate, discussion and friction (Ferreira et al., 2008), and no changes have been introduced so far in this respect by public authorities. Comments of respondents registered in the online survey were illustrative of this "binary tension" and also of a littoral/interior tension, as shown in the following examples:

The University (subsystem) systematically attacks and downgrades the Polytechnic because of the competition of the latter, forgetting that universities themselves are responsible for the present situation (blurred binary division);

The polytechnics have degenerated and are incapable of going back to functions that are socially integrated, technically important and above all, regionally useful;

Higher education should be restructured, the number of available places for students (in HEI) should decrease in the big cities and in littoral regions, for the benefit of interior regions.

Similarly to the NIMBY syndrome, the overall consensus about the need to reform the system, contradicts the strong divergence about the direction of that reform, contributing to a political conundrum still waiting to be disentangled.

Overall, the survey showed a strong relationship between HEI diversity and faculty perspectives. As in other countries, horizontal diversification of HEI was first introduced in Portugal through the creation of a vocational subsystem in order to broaden the access to HE. Later, the competition for student enrolment enhanced the 
vertical stratification of $\mathrm{HEI}$, therefore contributing to further expanding the diversity of institutions, also following international trends (de Weert, 2015). This study shows that the disparity of faculty perspectives about system changes in $\mathrm{HE}$ is closely related to these institutional differences driven by HE expansion. These findings may contribute to insights into other HE systems around the world where institutional diversification has been sought by public policies.

\section{Acknowledgments}

The authors are grateful to Jennifer Burdon, Tania Stadler and Matthew Larcombe for the English revision of the manuscript. Adelaide Freitas was supported by CIDMA Center for Research \& Development in Mathematics and Applications, and FCT Portuguese Science Foundation, within project UID/MAT/04106/2013. 


\section{References}

Almeida, A. N., \& Vieira, M. M. (2012). From University to Diversity: The Making of Portuguese Higher Education. In G. Neave \& A. Amaral (Eds.), Higher Education in Portugal 1974-2009: A Nation, a Generation (pp. 137-159). Dordrecht: Springer.

Amaral, A., \& Magalhães, A. (2005). Implementation of higher education policies: A Portuguese example. In A. Gornitzka, M. Kogan \& A. Amaral (Eds.), Reform and Change in Higher Education (pp. 117-134). Dordrecht: Springer.

Askling, B. (2001). Higher education and academic staff in a period of policy and system change. Higher Education, 41(1), 157-181

Blättler, A., Rapp, J.-M., Solà, C., Davies, H., \& Teixeira, P. (2013). Portuguese Higher Education: a View from Outside. Brussels.

Boer, H. d., \& Goedegebuure, L. (2007). 'Modern' governance and codes of conduct in Dutch higher education. Higher Education Research \& Development, 26(1), 4555. doi: 10.1080/07294360601166802

Bowden, J. A., \& Anwyl, J. (1983). Some Characteristics and Attitudes of Academics in Australian Universities and Colleges of Advanced Education. Higher Education Research \& Development, 2(1), 39-61. doi: 10.1080/0729436830020104

Burningham, K. (2000). Using the Language of NIMBY: A topic for research, not an activity for researchers. Local Environment, 5(1), 55-67

Cannizzo, F. (2016). The transformation of academic ideals: an Australian analysis. Higher Education Research \& Development, 35(5), 881-894. doi: 10.1080/07294360.2016.1138454

Carvalho, T. (2011). Shaping the 'new'academic profession. In G. Neave \& A. Amaral (Eds.), Higher Education in Portugal 1974-2009: A Nation, a Generation (pp. 329-352). Dordrecht: Springer.

Carvalho, T., \& Bruckmann, S. (2014). Reforming Portuguese Public Sector: A Route from Health to Higher Education. In C. Musselin \& P. N. Teixeira (Eds.), Reforming Higher Education (Vol. 41, pp. 83-102). Dordrecht: Springer Netherlands.

Coleman, J. S. (2009). Individual Interests and Collective Action. Cambridge: Cambridge University Press.

Couper, M. P., Kapteyn, A., Schonlau, M., \& Winter, J. (2007). Noncoverage and nonresponse in an Internet survey. Social Science Research, 36(1), 131-148

de Weert, E. (2015). Teaching and Research in Binary Systems of Higher Education: Convergent or Distinctive Profiles? In W. K. Cummings \& U. Teichler (Eds.), The Relevance of Academic Work in Comparative Perspective (pp. 75-90). Dordrecht: Springer.

Diefenbach, T. (2007). The managerialistic ideology of organisational change management. Journal of Organizational Change Management, 20(1), 126-144

Diogo, S., \& Brückmann, S. (2015). Managing the unmanageable: perceptions on institutional change of a Portuguese university foundation. Working Papers in Higher Education Studies, 1(1)

Efron, B., \& Tibshirani, R. J. (1994). An introduction to the bootstrap. Boca Raton: CRC press.

Evans, L. (2015). The worst of times? A tale of two higher education institutions in France: their merger and its impact on staff working lives. Studies in Higher Education, 1-19 
Ferreira, J. B., de Lourdes Machado, M., \& Santiago, R. (2008). The polytechnic higher education sector in Portugal. In J. S. Taylor, J. B. Ferreira, M. d. L. Machado \& R. Santiago (Eds.), Non-university higher education in Europe (pp. 191-214). Dordrecht: Springer.

Flora, B. H., \& Hirt, J. B. (2010). Educational consortia in a knowledge economy: Collaboration, competition, and organizational equilibrium. The Review of Higher Education, 33(4), 569-592

Fonseca, M., Encarnação, S., \& Justino, E. (2014). Shrinking Higher Education Systems: A Multi Scale Perspective. In G. Goastellec \& F. Picard (Eds.), Higher Education in Societies (pp. 127-147). Rotterdam: The SensePublishers.

Gamage, D. T. (1992). Organisational Change and Development: An Australian Case Study. Higher Education Research \& Development, 11(2), 175-190. doi: 10.1080/0729436920110206

Griffioen, D. M. E., \& de Jong, U. (2013). Academic drift in Dutch non-university higher education evaluated: A staff perspective. Higher Education Policy, 26(2), 173-191

Guri-Rosenblit, S., Šebková, H., \& Teichler, U. (2007). Massification and diversity of higher education systems: Interplay of complex dimensions. Higher Education Policy, 20(4), 373-389

Hay, D., \& Fourie, M. (2002). Preparing the way for mergers in South African higher and further education institutions: An investigation into staff perceptions. Higher Education, 44(1), 115-131

Henkel, M. (2016). Multiversities and academic identities Change, continuities, and complexities. In L. Leisyte \& U. Wilkesmann (Eds.), Organizing Academic Work in Higher Education: Teaching, Learning and Identities (pp. 205-222). Oxon: Routledge.

Huisman, J., \& Kaiser, F. (Eds.). (2001). Fixed and fuzzy boundaries in higher education: a comparative study of (binary) structures in nine countries. The Hague: AWT.

Kauko, J., \& Diogo, S. (2012). Comparing higher education reforms in Finland and Portugal. Higher education management and policy, 23(3), 1-20

Kerr, C. (1963). The Idea of a Multiversity. In C. Kerr (Ed.), The Uses of the University (Vol. 1-45). Cambridge: Harvard University Press.

Magalhães, A., Amaral, A., \& Tavares, O. (2009). Equity, Access and Institutional Competition. Tertiary Education and Management, 15(1), 35-48

Mahony, D. (1990). The Rise of the Australian Comprehensive University. Higher Education Research \& Development, 9(1), 7-20. doi: 10.1080/0729436900090102

Mahony, D. (1994). A Comparison of the Australian and British Post Binary Higher Education Systems. Higher Education Research \& Development, 13(1), 71-84. doi: 10.1080/0729436940130107

Mahony, D. (1995). Academics in an Era of Structural Change: An Australian Experience. Higher Education Research \& Development, 14(1), 87-105. doi: $10.1080 / 0729436950140108$

Moser, C. A., \& Kalton, G. (2017). Survey methods in social investigation: Routledge.

O'Meara, K., \& Bloomgarden, A. (2011). The pursuit of prestige: The experience of institutional striving from a faculty perspective. The Journal of the Professoriate, 4(1), 40-74

Pruvot, E. B., Eastermann, T., \& Mason, P. (2015). DEFINE Thematic Report: University mergers in Europe. Brussels: E. U. Association. 
Puusa, A., \& Kekäle, J. (2015). Feelings over facts - a university merger brings organisational identity to the forefront. Journal of Higher Education Policy and Management, 37(4), 432-446

R Core Team. (2015). R: A language and environment for statistical computing. R Foundation for Statistical Computing. Vienna, Austria.

Ritzen, J. (2015). European universities during the crisis: A public policy perspective, with a brief excursion to the US, IZA Policy Paper 107

Santiago, R., Carvalho, T., \& Cardoso, S. (2015). Portuguese academics' perceptions of higher education institutions' governance and management: a generational perspective. Studies in Higher Education, 40(8), 1471-1484

Schubert, T., Bonaccorsi, A., Brandt, T., Filippo, D. D., Lepori, B., Niederl, A., ... Sliepersaeter, S. (2014). Is There a European University model? New Evidence on National Path dependence and Structural Convergence. In A. Bonaccorsi (Ed.), Knowledge, Diversity and Performance in European Higher Education: a Changing Landscape (pp. 47-83). Cheltenham: Edward Elgar Publishing.

Shanahan, T., \& Jones, G. A. (2007). Shifting roles and approaches: government coordination of post- secondary education in Canada, 1995-2006. Higher Education Research \& Development, 26(1), 31-43. doi: 10.1080/07294360601166794

Skodvin, O. J. (1999). Mergers in Higher Education--Success or Failure? Tertiary Education and Management, 5(1), 63-78

Sutton, P. (2017). Lost souls? The demoralization of academic labour in the measured university. Higher Education Research \& Development, 36(3), 625-636. doi: 10.1080/07294360.2017.1289365

Teichler, U. (2008). The end of alternatives to universities or new opportunities? In J. S. Taylor, J. B. Ferreira, M. d. L. Machado \& R. Santiago (Eds.), Non-university higher education in Europe (pp. 1-13). Dordrecht: Springer.

Verhoeven, J. C. (2008). Questioning the binary divide: Non-university higher education in Flanders (Belgium). In J. S. Taylor, J. B. Ferreira, M. d. L. Machado \& R. Santiago (Eds.), Non-university higher education in Europe (pp. 43-75). Dordrecht: Springer.

Witte, J., Van der Wende, M., \& Huisman, J. (2008). Blurring boundaries: How the Bologna process changes the relationship between university and nonuniversity higher education in Germany, the Netherlands and France. Studies in Higher Education, 33(3), 217-231

Ylijoki, O. H. (2014). University Under Structural Reform: a Micro-Level Perspective. Minerva, 1(52), 55-75 